\title{
Road rage in Sri Lanka: prevalence and psychiatric distress
}

\author{
A Rodrigo'1, D Perera 1 , V P Eranga 1 , M U P K Peris ${ }^{1}$, A Pathmeswaran²
}

\begin{abstract}
Introduction Road traffic accidents are a major public health concern in Sri Lanka. Aggressive and reckless driving is an important contributor to the high rate of road traffic accidents.
\end{abstract}

Objective We studied prevalence, nature, determinants and associated psychiatric morbidity of road rage among motorists in Sri Lanka.

Methods Data were gathered from 238 randomly selected motorists in Sri Lanka using a modified questionnaire regarding road rage and the 6-item version of Kessler's psychological distress scale.

Results While $98.7 \%$ participants reported being victims of road rage, $85.3 \%$ were involved in offending behaviour. However actual physical assault $(0.8 \%)$ and damage to vehicles $(2.5 \%)$ were rare. Male gender, young age, increased traffic density and driving a three-wheeler or bus were associated with daily road rage victimisation and perpetration. Psychiatric distress was associated with being a victim of road rage.

Conclusions High prevalence of road rage in Sri Lanka and significant psychiatric distress associated with it indicate the necessity of interventions at least for target groups.

Ceylon Medical Journal 2015; 60: 86-90

\section{Introduction}

Road traffic accidents (RTA) are a major global public health problem which accounts for 1.24 million deaths and between 20 to 50 million injuries a year respectively [1,2]. It is estimated that road traffic injuries would be the third leading contributor to global disease burden by 2020 [3]. In Sri Lanka, in 2010, 26,847 were seriously injured, and 2,721 people died ( $2 \%$ of all deaths) as a result of RTA, [4]. The casualties related to RTA have increased over the last few years and this trend is expected to continue with the expansion of the road network including highways.

Aggressive and reckless driving has been identified as one of the leading causes of transport injuries both

Departments of ${ }^{1} P$ sychiatry and ${ }^{2}$ Public Health, Faculty of Medicine, University of Kelaniya, Sri Lanka.

Correspondence: AR, e-mail: <asirir2000@yahoo.com>. Received 23 August 2014 and revised version accepted 6 June 2015. 
internationally and locally $[5,6]$. Road rage is a main contributor to aggressive and reckless driving. The incidence of road rage in the US has increased by $7 \%$ per year in 1990s [5,7]. Although there is no clear consensus on the definition of road rage, it has been conceptualised as 'a situation where a driver or passenger attempts to kill, injure, or intimidate a pedestrian or another driver, or cause damage to their vehicle in a traffic incident' or 'any driving behaviour that intentionally endangers others psychologically, physically, or both' [5,7]. Research data on road rage is limited and predominantly comes from the West. Only a few studies on road rage have been conducted in Asia and none in Sri Lanka, hence the extent and profile of the issue remains largely unknown.

The determinants of road rage have been explored only in a few studies $[8,9]$. Young age, male gender, increased time behind the wheel, traffic density, poor driving of others, general stress, tendency to blame others and displaced anger are contributory factors for road rage [8-11]. While perpetrators of road rage are known to have substance misuse disorders, depressive and anxiety symptoms and cluster B personality traits, victims of road rage can result in depression and post-traumatic stress disorder [8,12-15]. No studies regarding psychiatric morbidity and road rage are available from Asia.

We explored prevalence, nature, determinants and associated psychiatric distress of road rage in Sri Lanka.

\section{Method}

We conducted a cross-sectional descriptive study among motorists in Colombo, Gampaha and Ratnapura districts. The choice of these three districts were on convenience. While the two former districts have the highest population and traffic densities in the country, the latter is more rural [16]. Within each district we adopted a stratified sampling method to ensure representative participation of drivers of various categories such as buses/coaches, lorries, light vehicles (cars, sports utility vehicles, dual purpose vehicles, vans), three wheelers and motorcycles. Clusters of three wheeler stands, bus routes, container yards, work places (for light vehicles and motorcycles) were randomly selected using data available at local/ district authorities. All eligible participants in selected clusters at time of data collection, on weekday mornings, were invited to participate.

The collection of data was carried out using a three paged self-administered questionnaire in Sinhalese which included questions to elicit potential determinants of road rage and a survey assessing the perpetration and victimisation of road rage over the last five years by selfreport using a 5-point Likert type scale. The questionnaire was developed after studying similar previous surveys. $[11,15,17,18]$ Modifications to suit Sri Lanka were made following discussions with focus groups which consisted of professional drivers, traffic police officers, driving instructors and those who drive regularly (at least 4 days a week) for work. For our study road rage was defined as any deliberate driving behaviour which has potential to cause physical or psychological harm to others, ranging from angry tooting to attempting or harming other vehicles or individuals. This was the most commonly used definition. Participants were advised to concentrate more on the recent past if their road rage experiences were frequent, but were encouraged to consider a five year period if the incidents were infrequent. Considering a similar study in the region which recorded a prevalence rate of road rage at $79 \%$, the sample size was estimated as 250 [18].

The psychiatric distress of motorists was measured using the 6-item version of Kessler's psychological distress scale (K6) which has been validated as a self administered assessment in Sri Lanka [19]. Greater K6 scores indicate higher psychiatric distress and scores above 7 point towards psychiatric illnesses, particularly depression and anxiety.

Participants who were professional drivers such as drivers of buses, lorries and three wheelers were paid a sum of rupees one hundred as reimbursement for their time. Data analysis was done in two stages. First, a statistical overview of each road rage measure and how those measures varied across demographic indicators. How road rage victimisation and perpetration are associated with K6 scores was explored later.

\section{Results}

Two hundred and eighty individuals were approached of whom 8 declined participation and 34 returned incomplete questionnaires. Response rate was $85 \%$. One hundred and ninety eight males $(83.2 \%)$ and 40 females participated in the study and average age of participants was 38.4 years. The average driving experience of participants was 13.5 years (SD 8.6 years). The demographic details are shown in table 1. There was no significant difference in background characteristics between participants from the three districts.

All but 3 participants (98.8\%) reported being victims of road rage while $85.3 \%$ reported being perpetrators of offending behaviour. Those who were victimised more often were also more frequent perpetrators $(\mathrm{r}=0.6, p<0.01)$. Two participants had been assaulted and six vehicles were damaged as a result of road rage in the last five years. These serious forms of road rage were reported by three wheeler and bus drivers from Colombo.

Daily perpetration of all forms of road rage was significantly higher among male drivers when compared to females ( $40 \%$ vs. $25 \%$; $p=0.021$ ). Similarly, males were more likely to be daily victims of road rage ( $70 \%$ vs. $37.5 \%$; $p=0.001)$. Three wheeler and bus drivers $\left(\mathrm{X}^{2}=5.89, p=0.02\right)$, lower educational level (educated up to grade 10 or less) $\left(\mathrm{X}^{2}=5.59, p=0.02\right)$ and residing in Colombo or Gampaha districts $\left(\mathrm{X}^{2}=7.92, p=0.04\right)$ had significant associations with daily road rage victimisation. 
Table 1. Background characteristics of participants $(n=238)$

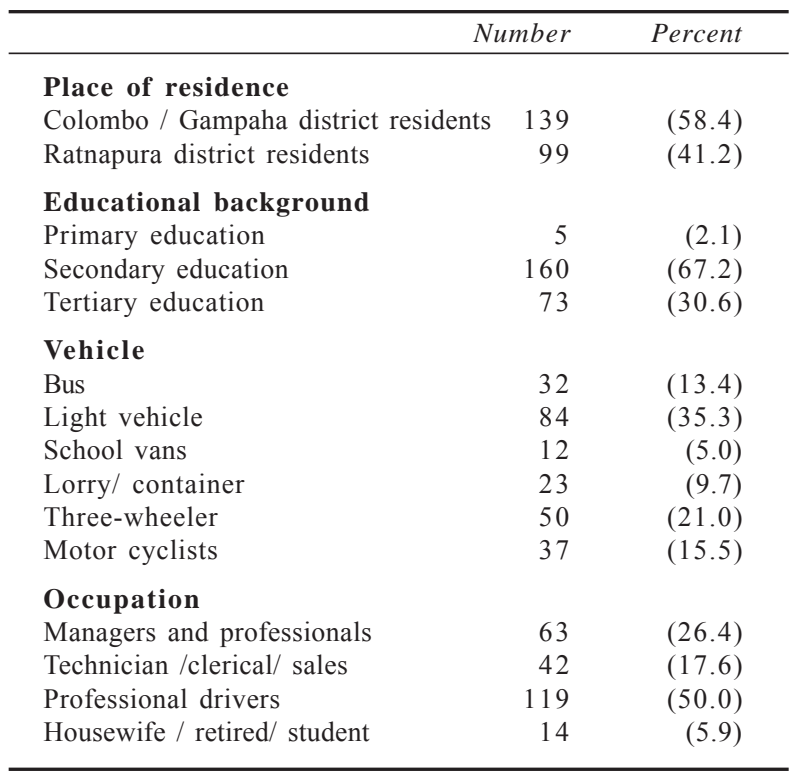

Of the participants $52.5 \%$ from Colombo and Gampaha districts and $68.7 \%$ from Ratnapura district found driving a pleasant experience. Thirty nine participants (16.4\%) reported their driving to be 'dangerous' and only few of them were from Ratnapura district. Bus and three wheeler drivers were over represented in the above category.

The frequency of road rage victimisation and perpetration by district are shown in Tables 2A and 2B.

Five participants (3.8\%) scored more than the cut-off score for mental illness and it is worth noting that all of them were male, daily road rage offenders. There was an association between frequency of road rage and average K6 scores though it was not statistically significant (Table 3). Free comment on their coping strategies with regard to road rage reported the following. One hundred and fifty one participants made comments and most common strategies were listening to music or radio, talking to someone and using relaxation techniques.

Table 2A. Frequency of road rage victimization by district

\begin{tabular}{|c|c|c|c|c|c|c|c|c|}
\hline & \multicolumn{2}{|c|}{ Once a day or more } & \multicolumn{2}{|c|}{$\begin{array}{l}\text { Once a week to } \\
\text { once a month }\end{array}$} & \multicolumn{2}{|c|}{ Less than once a month } & \multicolumn{2}{|c|}{ Never } \\
\hline & Group 1 & Group 2 & Group 1 & Group 2 & Group 1 & Group 2 & Group 1 & Group 2 \\
\hline $\begin{array}{l}\text { Angrily tooted at } \\
\text { you }\end{array}$ & $\begin{array}{l}89 \\
(64 \%)\end{array}$ & $\begin{array}{c}42 \\
(42 \%)\end{array}$ & $\begin{array}{c}36 \\
(26 \%)\end{array}$ & $\begin{array}{c}44 \\
(44 \%)\end{array}$ & $\begin{array}{c}14 \\
(11 \%)\end{array}$ & $\begin{array}{c}10 \\
(10 \%)\end{array}$ & $\begin{array}{c}0 \\
(0 \%)\end{array}$ & $\begin{array}{c}3 \\
(3 \%)\end{array}$ \\
\hline $\begin{array}{l}\text { Made rude } \\
\text { gestures at you }\end{array}$ & $\begin{array}{c}32 \\
(23 \%)\end{array}$ & $\begin{array}{c}9 \\
(9) \%\end{array}$ & $\begin{array}{c}32 \\
(23 \%)\end{array}$ & $\begin{array}{c}17 \\
(17 \%)\end{array}$ & $\begin{array}{c}60 \\
(43 \%)\end{array}$ & $\begin{array}{c}40 \\
(40 \%)\end{array}$ & $\begin{array}{c}15 \\
(11 \%)\end{array}$ & $\begin{array}{c}33 \\
(33 \%)\end{array}$ \\
\hline $\begin{array}{l}\text { Shouted at / } \\
\text { threatened you }\end{array}$ & $\begin{array}{c}6 \\
(4 \%)\end{array}$ & $\begin{array}{c}3 \\
(3 \%)\end{array}$ & $\begin{array}{c}43 \\
(31 \%)\end{array}$ & $\begin{array}{c}12 \\
(12 \%)\end{array}$ & $\begin{array}{c}60 \\
(43 \%)\end{array}$ & $\begin{array}{c}48 \\
(48 \%)\end{array}$ & $\begin{array}{c}30 \\
(22 \%)\end{array}$ & $\begin{array}{c}36 \\
(36 \%)\end{array}$ \\
\hline $\begin{array}{l}\text { Attempted to } \\
\text { damage your vehicle }\end{array}$ & $\begin{array}{c}0 \\
(0 \%)\end{array}$ & $\begin{array}{c}0 \\
(0 \%)\end{array}$ & $\begin{array}{c}16 \\
(11 \%)\end{array}$ & $\begin{array}{c}4 \\
(4 \%)\end{array}$ & $\begin{array}{c}64 \\
(46 \%)\end{array}$ & $\begin{array}{l}27 \\
(27 \%)\end{array}$ & $\begin{array}{c}59 \\
(42 \%)\end{array}$ & $\begin{array}{c}68 \\
(68 \%)\end{array}$ \\
\hline $\begin{array}{l}\text { Attempted to } \\
\text { hurt you }\end{array}$ & $\begin{array}{c}0 \\
(0 \%)\end{array}$ & $\begin{array}{c}0 \\
(0 \%)\end{array}$ & $\begin{array}{c}1 \\
(1 \%)\end{array}$ & $\begin{array}{c}0 \\
(0) \%\end{array}$ & $\begin{array}{c}19 \\
(14 \%)\end{array}$ & $\begin{array}{c}6 \\
(6 \%)\end{array}$ & $\begin{array}{l}119 \\
(86 \%)\end{array}$ & $\begin{array}{c}93 \\
(93 \%)\end{array}$ \\
\hline
\end{tabular}

Group 1. Colombo and Gampaha districts; group 2. Ratnapura district

Table 2B. Frequency of road rage perpetration by district

\begin{tabular}{|c|c|c|c|c|c|c|c|c|}
\hline & \multicolumn{2}{|c|}{ Once a day or more } & \multicolumn{2}{|c|}{$\begin{array}{l}\text { Once a week to } \\
\text { once a month }\end{array}$} & \multicolumn{2}{|c|}{ Less than once a month } & \multicolumn{2}{|c|}{ Never } \\
\hline & Group 1 & Group 2 & Group 1 & Group 2 & Group 1 & Group 2 & Group 1 & Group 2 \\
\hline $\begin{array}{l}\text { Angrily tooted at } \\
\text { others }\end{array}$ & $\begin{array}{c}57 \\
(41 \%)\end{array}$ & $\begin{array}{c}21 \\
(21 \%)\end{array}$ & $\begin{array}{c}42 \\
(30 \%)\end{array}$ & $\begin{array}{c}28 \\
(28 \%)\end{array}$ & $\begin{array}{l}22 \\
(16 \%)\end{array}$ & $\begin{array}{c}30 \\
(30 \%)\end{array}$ & $\begin{array}{c}18 \\
(13 \%)\end{array}$ & $\begin{array}{c}20 \\
(20 \%)\end{array}$ \\
\hline $\begin{array}{l}\text { Made rude gestures } \\
\text { at others }\end{array}$ & $\begin{array}{c}8 \\
(6 \%)\end{array}$ & $\begin{array}{c}1 \\
(1 \%)\end{array}$ & $\begin{array}{l}21 \\
(15 \%)\end{array}$ & $\begin{array}{c}7 \\
(7 \%)\end{array}$ & $\begin{array}{c}42 \\
(30 \%)\end{array}$ & $\begin{array}{c}25 \\
(25 \%)\end{array}$ & $\begin{array}{c}68 \\
(49 \%)\end{array}$ & $\begin{array}{l}66 \\
(66 \%)\end{array}$ \\
\hline $\begin{array}{l}\text { Attempted to } \\
\text { damage other vehicle }\end{array}$ & $\begin{array}{c}0 \\
(0 \%)\end{array}$ & $\begin{array}{c}0 \\
(0 \%)\end{array}$ & $\begin{array}{c}8 \\
(6 \%)\end{array}$ & $\begin{array}{c}0 \\
(0 \%)\end{array}$ & $\begin{array}{c}32 \\
(23 \%)\end{array}$ & $\begin{array}{l}7 \\
(7 \%)\end{array}$ & $\begin{array}{c}99 \\
(71 \%)\end{array}$ & $\begin{array}{c}92 \\
(92 \%)\end{array}$ \\
\hline $\begin{array}{l}\text { Attempted to hurt } \\
\text { others }\end{array}$ & $\begin{array}{c}0 \\
(0 \%)\end{array}$ & $\begin{array}{c}0 \\
(0 \%)\end{array}$ & $\begin{array}{l}0 \\
(0) \%\end{array}$ & $\begin{array}{c}0 \\
(0) \%\end{array}$ & $\begin{array}{l}12 \\
(9 \%)\end{array}$ & $\begin{array}{c}1 \\
(1 \%)\end{array}$ & $\begin{array}{l}127 \\
(91 \%)\end{array}$ & $\begin{array}{l}98 \\
(98 \%)\end{array}$ \\
\hline
\end{tabular}

Group 1. Colombo and Gampaha districts; group 2. Ratnapura district 


\section{Table 3. Psychiatric distress and frequency of road rage victimisation and perpetration}

\begin{tabular}{lcccc}
\hline & $\begin{array}{c}\text { Once a } \\
\text { day or } \\
\text { more }\end{array}$ & $\begin{array}{c}\text { Once a week } \\
\text { to once } \\
\text { a month }\end{array}$ & $\begin{array}{c}\text { Less than } \\
\text { once } a \\
\text { month }\end{array}$ & Never \\
\hline $\begin{array}{l}\text { Average K6 } \\
\text { score of victims } \\
\text { of road rage }\end{array}$ & 2.16 & 1.30 & 0.86 & 0.0 \\
$(\mathrm{n}=132)$ & $(\mathrm{n}=83)$ & $(\mathrm{n}=21)$ & $(\mathrm{n}=3)$ \\
$\begin{array}{l}\text { Average K6 } \\
\text { score of road } \\
\text { rage perpetrators }\end{array}$ & $\begin{array}{l}2.91 \\
(\mathrm{n}=81)\end{array}$ & $\begin{array}{c}1.49 \\
(\mathrm{n}=80)\end{array}$ & $\begin{array}{c}1.30 \\
(\mathrm{n}=42)\end{array}$ & $\begin{array}{c}0.68 \\
(\mathrm{n}=35)\end{array}$ \\
\hline
\end{tabular}

\section{Discussion}

Our study shows that road rage on Sri Lankan roads is higher than international and regional prevalence of road rage $[11,15,18]$. It has been discussed that the absence of a universally agreed definition makes it difficult to compare studies [5]. Inclusion of aggressive tooting and over representation of professional drivers who are more likely to experience road rage may explain the higher prevalence in our study $[11,15,18]$. Comparatively low serious forms of aggression may suggest tooting as a protective factor against aggression. The results show that road rage is more likely to be experienced by young male drivers of buses and three-wheelers in high-traffic density areas, as demonstrated in studies elsewhere [8-11].

Previous studies have repeatedly demonstrated that less patience and more aggression being shown towards 'low status' vehicles [20]. This may partly explain the high victimisation of road rage reported by drivers of buses and three-wheelers. At the same time, increased offending behaviour by same group of drivers may be related to the association between road rage and more time behind the wheel, greater exposure to traffic congestion and economic constraints $[8,15,20]$. Factors such as relatively low traffic congestion and higher social connectedness leading to less anonymity of drivers may have contributed to the lower road rage prevalence seen in Ratnapura District. While the finding from previous studies that male drivers were more aggressive than female drivers is supported by the results of this study, our findings did not support the claim from previous studies that female drivers engaged in more covert forms of aggression such as losing temper than male drivers $[8,9,20]$.

Both victims and offenders of road rage were more likely to score higher on K6. Studies suggest victims are prone to develop post traumatic stress disorder and depression and individuals with these symptoms are likely to have higher K6 scores [13-15,19]. It has also been demonstrated that perpetration of road rage may be part of a larger psychiatric phenomenon such as issues with anger management, impulse control, mood instability and substance use $[9,13-15,20]$.
Although psychological interventions specifically targeting road rage are relatively limited, available studies report positive results following such interventions $[20,21]$. Cognitive behavioural therapy techniques such as psychoeducation, relaxation, motivational enhancement, cognitive restructuring and behavioural modifications reduce aggressive driving in court- and selfreferred participants [20,21]. Galovski and Blanchard noted that the success of those interventions was dependent on self-acceptance of their "aggressive driver" status [21]. It is rather promising to see that significant portion of frequent offenders in our study identified their driving as dangerous making them suitable candidates for such interventions. Considering high prevalence of road rage and traffic injuries in Sri Lanka, introduction of such interventions may be useful.

A significant limitation of this study is the possibility of sample bias. The respondents were those literate in Sinhala and were from three districts only which may not be representative of the rest of the country. The division of three districts in to urban and rural may be arbitrary as each district has both urban and rural areas, however the first two districts had more urban areas hence participants from those are more likely to encounter such situations when compared to the third district. Numerous studies have shown that violence and aggression are more common among heavy drinkers $[6,8,12,14,15]$. Our study did not explore the link between drinking and road rage.

\section{Conflicts of interest}

There are no conflicts of interest.

\section{References}

1. Peden M. Global collaboration on road traffic injury prevention. International Journal of Injury Control Safety Promotion 2005; 12: 85-91.

2. World Health Organization. Global status report on road safety 2013: supporting a decade of action. Geneva: WHO, 2013.

3. Murray CJ, Lopez AD. Alternative projections of mortality and disability by cause 1990-2020: Global Burden of Disease Study. Lancet 1997; 349: 1498-504.

4. de Winter JC, Dodou D. The Driver Behaviour Questionnaire as a predictor of accidents: a meta-analysis. J Safety Res 2010; 41: 463-70.

5. Dula CS, Geller ES. Risky, aggressive, or emotional driving: addressing the need for consistent communication in research. J Safety Res 2003; 34: 559-66.

6. Kumarage AC, Abeygoonawardene CR, Wijesundara R. Identifying causal factors of traffic accidents in Sri Lanka Available at http://iesl.ceylonhost.com/IESL_publications/ Civil\%20Engineering/Transportation $\% 20 \& \% 20$ Traffic $\% 20$ Engineering/Identifying $\% 20$ Causal $\% 20$ Factors $\% 20$ of $\% 20$ Traffic $\% 20$ Accidents $\% 20$ In $\% 20$ Sri $\% 20$ Lanka\%20by\%20Amal\%20S.\%20Kumarage\%20,\%20C. R.\%20Abeygoonawardena\%20\&\%20Ravindra\%20 Wijesundera\%202000.PDF 


\section{Papers}

7. Smart RG, Mann, RE. Is road rage a serious traffic problem? J Traffic Med 2002; 3: 183-9.

8. Sansone RA, Sansone LA. Road Rage: What's Driving It? Psychiatry (Edgmont) 2010; 7: 14-8.

9. Smart RG, Mann RE. Deaths and injuries from road rage: cases in Canadian newspapers. Canadian Med Association J 2002; 167: 761-2.

10. Smart R, Stoduto G, Mann R, Adlaf E. Road rage experience and behavior: vehicle, exposure, and driver factors. Traffic Injury Prev 2004; 5: 343-8.

11. Lupton D. Road rage: drivers' understandings and experiences. J Sociol 2002; 38: 275-90.

12. Butters JE, Smart RG, Mann RE, Asbridge M. Illicit drug use, alcohol use and problem drinking among infrequent and frequent road ragers. Drug and Alcohol Dependence 2005; 80: 169-75.

13. Smart RG, Asbridge M, Mann RE, Adlaf EM. Psychiatric distress among road rage victims and perpetrators. Canadian J Psy 2003; 48: 681-8.

14. Dumais A, Lesage AD, Boyer R, et al. Psychiatric risk factors for motor vehicle fatalities in young men. Canadian J Psy 2005; 50: 838-44.
15. Fong G, Frost D, Stansfeld S. Road rage: a psychiatric phenomenon? Social Psychiatry and Psy Epid 2001; 36: 277-86.

16. Department of Census and Statistics. Brief Analysis of Population and Housing Characteristics http:// www.statistics.gov.lk/PopHouSat/PDF/p7\%20population \%20and\%20Housing\%20Text-11-12-06.pdf

17. DePasquale JP, Geller ES, Clarke SW, Littleton LC. Measuring road rage: Development of the Propensity for Angry Driving Scale. J Safety Res 2001; 32: 1-16.

18. Shaikh MA, Shaikh IA, Siddiqui Z. Road rage behaviour and experiences of rickshaw drivers in Rawalpindi, Pakistan. Eastern Mediterranean Health J 2011; 17: 719-21.

19. Wijeratne LT, Williams SS, Rodrigo MDA, Peris MUPK, Kawamura N, Wickremasinghe AR. Validation of the Kessler's psychological distress scale among the Sinhalese population in Sri Lanka. South Asian J Psy 2011; 2: 21-5.

20. Galovski TE, Blanchard EB. Road rage: a domain for psychological intervention? Aggression and Violent Behavior 2004; 9: 105-27.

21. Deffenbacher JL, Huff ME, Lynch RS, Oetting ER, Salvatore NF. Characteristics and treatments of high-anger drivers. J Consulting Psy 2000; 47: 5-17. 